\title{
Effects of Silybum marianum Aqueous Extract and L-carnitine on Stereological Changes in Diazinon-Treated Rat Liver
}

\author{
Masoumi F, Shariati M, Mokhtari M \\ Department of Biology, Kazerun Branch, Islamic Azad University, Kazerun, Iran \\ *E-mail: mehrdadshariati@kau.ac.ir \\ (received 22-02-2020 ; revised 30-03-2020; accepted 30-03-2020)
}

\begin{abstract}
ABSTRAK
Masoumi F, Shariati M, Mokhtari M. 2020. Pengaruh sari ekstrak Silybum marianum dan l-carnitine pada perubahan stereologi hati tikus yang diberikan perlakuan diazinon. JITV 25(2):91-98. DOI: http://dx.doi.org/10.14334/jitv.v25i2.2467

Sebagai senyawa organiphosphorus, diazinon (DZN) dapat menggangu fungsi jaringan hati dengan menghambat asetinkolinesterase dan menyebabkan tekanan oksidatif. Dalam penelitian ini, pengaruh ektrak sari Silybum marianum (SMAE) dan L-carnitine (LC) pada perubahan stereologi dan histopatologi hati tikus jantan yang diberi perlakuan DZN diamati. Tikus-tikus ditempatkan dalam 9 kelompok dengan masing-masing sebanyak 8 ekor terdiri dari kontrol, plasebo dan kombinasi DZN, SMAE dan LC. SMAE dan bahan kimia lainnya diberikan kepada tikus coba secara oral selama 30 hari. Setelah itu, jaringan hati semua tikus coba dikeluarkan. Bagian jaringan hati disiapkan untuk melihat penanda stereologis termasuk volume dan berat hati, volume hepatosit, volume vena sentral, volume sinusoidal, volume jaringan ikat, laju peradangan, dan jumlah inti hepatosit. Juga, jaringan sampel dievaluasi secara histopatologis. Pengobatan dengan DZN secara signifikan mengurangi volume dan berat hati, volume hepatosit, volume vena sentral, volume sinusoidal, dan jumlah nukleus hepatosit dibandingkan dengan kelompok plasebo dan kontrol tetapi secara signifikan meningkatkan peradangan dan volume jaringan ikat hati. Namun, pemberian SMAE dan LC bersamaan dengan DZN meningkatkan volume dan berat hati, volume hepatosit, volume vena sentral, volume sinusoidal, volume jaringan ikat, dan jumlah inti hepatosit sendiri dibandingkan dengan pengobatan DZN. Peradangan hati juga menurun secara signifikan dibandingkan dengan pengobatan DZN tetapi jika dibandingkan dengan kelompok plasebo dan kontrol, hal itu meningkat secara signifikan. Pemberian SMAE dan LC secara simultan memiliki efek perlindungan pada jaringan hati dan dapat mengurangi cedera hati yang disebabkan oleh DZN pada tikus.
\end{abstract}

Kata Kunci: Diazinon, L-carnitine, Hati, Tikus, Silybum marianum

\begin{abstract}
Masoumi F, Shariati M, Mokhtari M. 2020. Effects of Silybum marianum aqueous extract and 1-carnitine on stereological changes in diazinon-treated rat liver. JITV 25(2):91-98. DOI: http://dx.doi.org/10.14334/jitv.v25i2.2467

As an organophosphorus, Diazinon (DZN) impairs liver tissue function by inhibiting acetylcholinesterase and causing oxidative stress. In this study, the effects of Silybum marianum aqueous extract (SMAE) and L-carnitine (LC) on the stereological and histopathological changes of the liver in DZN-treated male rats were investigated. The rats in this study were placed into 9 groups of 8 each containing control, placebo, and a combination of DZN, SMAE, and LC. The animals received SMAE and chemicals orally for 30 days. At last, the liver tissue of all animals was removed. Then, tissue sections from the liver were provided to study the stereological markers including liver volume and weight, hepatocytes' volume, central venous volume, sinusoidal volume, connective tissue volume, inflammation rate, and a number of the hepatocytes' nuclei. Also, the sample tissues were evaluated histopathologically. Treatment with DZN significantly reduced the liver volume and weight, hepatocyte volume, central venous volume, sinusoidal volume, and hepatocyte nucleus number compared to placebo and control but it significantly increased the inflammation and volume of liver's connective tissue. However, co-administration of SMAE and LC with DZN improved liver volume and weight, hepatocyte volume, central venous volume, sinusoidal volume, connective tissue volume, and hepatocyte nucleus number alone compared to the DZN treatment. Liver inflammation was also significantly decreased compared to the DZN treatment but comparing to the placebo and control groups, it increased significantly. Simultaneous administration of SMAE and LC has protective effects on liver tissue and can reduce DZN-induced liver injury in rats.
\end{abstract}

Key Words: Diazinon, L-carnitine, Liver, Rat, Silybum marianum 


\section{INTRODUCTION}

Medicinal herbs are currently considered as a viable alternative to chemical drugs due to their ease of access, reduced side effects and reasonable prices (Karimi et al. 2015). Most medicinal plants can prevent the damage caused by free radicals due to their antioxidant properties (Nasri 2013). Some crude herbal extracts used in traditional medicine are rich in compounds with preventive and protective properties, especially in the liver (Xiong \& Guan 2017).

Silybum marianum (SM) is one or two year old plant from Cichorium family that grows in warm climates. This plant is native to western and central Europe, northern India, and today grows in southern Europe, Africa, China and Australia, South America, and Asia and is widely distributed in Iran. The fruits of this plant contain a group of flavonoid compounds called silymarin. Silymarin is composed of silybin, silydianine, silychristine, and isosilybin (Bijak 2017; Abenavoli et al. 2018). The reports have suggested that silymarin may exert its effects on liver cells in three ways: 1) It binds to the membrane receptor of the liver cells that uptakes the toxins and modifies their phospholipid composition to prevent their uptake, 2) Because it is a potent antioxidant, it inhibits lipid peroxidation by preventing metabolism abnormalities, especially in liver cells, 3) By stimulating protein synthesis, it induces liver cell regeneration (Surai 2015).

Nowadays, various pesticides are used in the agricultural industry to increase the quality and quantity of crops to combat pests. Diazinon toxin is an organophosphate compound used to control insects in the agricultural industry. Diazinon is a colorless, oily and liquid toxicant that inhibit the acetylcholinesterase enzyme which is essential for the functioning of the nervous system (Duysen et al. 2012).

Diazinon, as an environmental pollutant, has a lengthy half-life in the environment and therefore can be hazardous to human health (Jones et al. 2015). Diazinon increases the risk of genetic syndromes, including Turner syndrome, by altering sperm chromosomes (Slotkin \& Seidler 2012). The expanding use of organophosphates, especially DZN, and numerous reports in recent years on the effects of anomalies of these pesticides on various developmental processes has raised many concerns about the harmful effects of such toxins on human health. Organophosphorus appears to alter cell function, gene mutation, stop mitotic division, fetal malformation, stop DNA synthesis, and induce cell death. Therefore, based on the reported effects of these toxins, they are classified in the group of cytotoxic and genotoxic compounds (Slotkin \& Seidler 2012; Newcomb et al. 2005). Recent studies have shown that acute and chronic toxicity with organophosphorus compounds, including DZN, induces free radicals through the induction of oxidative stress and thereby changes the balance of the body's antioxidant system and provides the conditions for pathological changes in the body (Anbarkeh et al. 2014). Indeed, exposure to DZN causes severe histopathologic damages in the liver including sinusoidal dilatation, disrupt of hepatocytes, vacuolization of hepatocyte cytoplasm, and centrilobular necrosis (Beydilli et al. 2015).

L-carnitine (LC) is produced in the body through diet, biosynthesis and utilizing essential amino acids like lysine and methionine (Ghoreyshi et al. 2019). Transferring long-chain fatty acids from the mitochondrial inner membrane for beta-oxidation and producing ATP in diverse tissues are among the important physiological roles of LC. L-carnitine prevents oxidative stress and regulates nitric oxide, cellular respiration and activity of enzymes involved in oxidative stress. Its role as a free radical scavenger in aging has been also described (Murali et al. 2015).

The liver, as the most important organ of the body's metabolism, plays a key role in many essential physiological processes such as glucose homeostasis, production of essential plasma proteins, lipoproteins and lipids, production and secretion of bile acids and storage of vitamins (Trefts et al. 2017). In addition, due to its major role in detoxification of toxins with internal and external origin, liver is constantly exposed to various types of high concentrations of toxins. There is extensive evidence that free radicals and reactive oxygen species play a key role in initiating and regulating the different stages of liver disease. Even small amounts of antioxidants found in food and body are used to protect body against different types of oxidative damage which are caused by oxygen free radicals (Hodges \& Minich 2015). This study was conducted to investigate the effects of LC and SMAE alone and in compound form on the stereological and histopathological changes of liver tissue in DZN-treated male rats.

\section{MATERIALS AND METHODS}

\section{Animals}

In this experimental study, 72 adult male Wistar rats were obtained from the animal house of Islamic Azad University, Kazerun, Iran, which was approximately 10 weeks old and weighing $220 \pm 20 \mathrm{~g}, 22 \pm 2^{\circ} \mathrm{C}, 12$ hours on the light and 12-hour on the darkness and $70 \%$ humidity were the standard conditions in which the animals were kept. To adapt to the new environmental conditions, the animals were kept for 2 weeks with the mentioned standard conditions. During the study, the animals had adequate and free access to pelleted food and water. All 
experiments were undertaken based on Iran Veterinary Organization rules and regulations for working with laboratory animals and the ethical committee of the Islamic Azad University of Kazerun, Iran approved all the ethical considerations on animal care. (Ethical Code No: IR.Kiau.15230509971001).

\section{Preparing the plant extract}

The stems and seeds of the SM were first dried and then powdered. One hundred $\mathrm{g}$ of the powder was added to $500 \mathrm{ml}$ of distilled water and mixed well and then kept at room temperature for 24 hours. The resulting mixture was stirred using a magnetic heating stirrer at $60^{\circ} \mathrm{C}$ for 1 hour. The extract was centrifuged at $10,000 \mathrm{rpm}$ for 20 minutes and then filtered. The extract was kept in the refrigerator until use (Sajadi et al. 2016).

\section{Preparing chemicals}

L-carnitine was purchased from Merck INC. (Germany) and DZN with a purity of $95 \%$ was purchased from Sam Gol Company (Iran).

\section{Experimental protocol}

Animals were randomly divided into 9 equal groups $(n=8)$ of control, placebo, DZN15, SMAE100, LC300, SAME100+LC300, DZN15+LC300, DZN15+SMAE300 and DZN15+SMAE100+LC300 as follows:

a. Control group: received nothing except water and food.

b. Placebo group: only received $1 \mathrm{~mL}$ distilled water orally.

c. DZN15 group: received $15 \mathrm{mg} / \mathrm{kg}$ DZNtoxin orally at 6 p.m.

d. SMAE100 group: received $100 \mathrm{mg} / \mathrm{kg}$ of SMAE orally at 8 a.m.

e. LC300 group: received $300 \mathrm{mg} / \mathrm{kg} \mathrm{LC}$ orally at 8 a.m.

f. SAME100+LC300 group: received $100 \mathrm{mg} / \mathrm{kg}$ of SMAE and $300 \mathrm{mg} / \mathrm{kg}$ LC orally at 8 a.m.

g. DZN15+LC300 group: received $15 \mathrm{mg} / \mathrm{kg}$ DZN toxin at $6 \mathrm{p} . \mathrm{m}$. and $300 \mathrm{mg} / \mathrm{kg}$ LC orally at 8 a.m.

h. DZN15+SMAE300 group: received $15 \mathrm{mg} / \mathrm{kg}$ DZN toxin at 6 p.m. and $100 \mathrm{mg} / \mathrm{kg}$ SMAE orally at 8 a.m.

i. DZN15+SMAE100+LC300 group: received 15 $\mathrm{mg} / \mathrm{kg}$ DZN toxin at 6 p.m. and $100 \mathrm{mg} / \mathrm{kg}$ SMAE along with $300 \mathrm{mg} / \mathrm{kg}$ LC orally at 8 a.m. SAME, DZN and LC doses were selected based on previous studies (Sajadi et al. 2016; Hussei et al. 2014).
On the day $31^{\text {st }}$, all animals were anesthetized with ether (Merck, Germany) and then were euthanized by cervical dislocation. Then, the abdominal area of each animal was opened and the liver tissue was removed. The removed specimens were fixed in $10 \%$ formalin buffer solution for fixation and blocked in paraffin after tissue passage and serial sections were prepared using a microtome machine for stereological and histopathological studies.

\section{Stereological study}

At the last stage, the rats' weight was measured and then forfeited. The liver was weighed, and the initial volume (V primary) was attained via the Scherle method (Scherle 1970; Zare et al. 2019). Isotropic identical random sections were acquired by the orientation method". Then, on average, 9-12 slabs were picked from each liver randomly. A circle was pressed out from a liver slab by a trocar. All the collected slabs and the circular pieces were implanted in the same paraffin block $5 \mu \mathrm{m}$ and $25 \mu \mathrm{m}$ sections were gained. After staining of $25 \mu \mathrm{m}$ tissue sections with Hematoxylin-Eosin, they were mounted with a coverslip. The diameters of the circular piece of the liver and the area of the circle were getting quantified once more to approximately obtain the global grade of liver tissue shrinkage. The shrinkage degree was calculated using the formula below:

Degree of shrinkage: $\left.1-\left(\frac{\mathrm{AA}}{\mathrm{AB}}\right)\right)^{1.5}$

where, $\mathrm{AA}$ is the area of the circular piece after and $\mathrm{AB}$ is the area of the circular piece before handling and staining, respectively.

Estimation of liver's hepatocytes, sinusoids, central veins, connective tissue volume or fibrosis in the experimental group

The following formula was used to assess the total volume of the hepatocytes, sinusoids, central veins, connective tissue or fibrosis, and inflammatory area.

$$
\left.\mathrm{Vv}(\text { structure })=\sum_{\mathrm{i}=1}^{\mathrm{n}} \mathrm{p}(\text { structure }) / \sum_{\mathrm{i}=1}^{\mathrm{n}} \text { (reference }\right)
$$

where, " $\Sigma \mathrm{P}_{\text {structure }}$ was considered as the number of points hitting the profiles of the hepatocytes, sinusoids, central veins, connective tissue and inflammatory area tissue and " $\Sigma \mathrm{P}$ reference" was considered as the number of points hitting the liver:

$$
\mathrm{V}\left({ }_{\text {structure }}\right)=\mathrm{Vv}(\text { structure/liver }) \times \mathrm{V} \text { final }
$$




\section{The hepatocytes' nuclei total number}

Using the Stereolite software and the optical dissector method with the following formula, the total number of hepatocytes 'nuclei was evaluated as mentioned before:

$$
N V=\frac{\sum_{i=1}^{n} Q}{\left(\sum \mathrm{P} \times \mathrm{h} \times \mathrm{a} / \text { frame }\right)} \times \frac{\mathrm{t}}{\mathrm{BA}}
$$

where $\Sigma \mathrm{Q}$ was considered as the number of the whole hepatocytes 'nuclei which were counted in all the dissectors, h was considered as the height of the optical dissector, a/frame was considered as the area of the counting frame, $\Sigma$ p was considered as the total number of the counted frames, BA was considered as the microtome block advance to cut the block, and finally, it was considered as the mean of the final section thickness.

\section{Statistical analysis}

Using SPSS software version 20, the normality of data was confirmed by the Kolmogorov-Smirnov test and the data analyzed using one-way ANOVA and LSD test at $\mathrm{P}<0.05$. The results were expressed as mean \pm standard deviation in the diagrams using GraphPad Prism software version 6 .

\section{RESULTS AND DISCUSSION}

\section{Results}

\section{Stereological findings}

Liver weight and volume, hepatocyte volume, central venous volume, and sinusoid volume and hepatocyte nucleus number (Figure $1 \mathrm{~A}-1 \mathrm{~F}$ ) were significantly decreased in the DZN15 group compared to the control and placebo groups $(\mathrm{P}<0.05)$. There was no significant difference between the SMAE100, LC300, and SAME100+LC300 groups with the control and placebo groups $(\mathrm{P}>0.05)$. No significant difference was observed in DZN15+LC300 and DZN15+SMAE100 groups with the control and placebo $(\mathrm{P}>0.05)$.

\section{The inflammation rate}

The level of inflammation (Figure 1G) was significantly increased in the DZN15 group compared to the control and placebo groups $(\mathrm{P}<0.05)$. No significant difference was observed between SMAE100, LC300 and SAME100+LC300 groups with control and placebo groups $(\mathrm{P}>0.05)$. A significant decrease in the inflammation of liver tissue was observed in DZN15+LC300, DZN15+SMAE100 and DZN15+SMAE100+LC300 groups compared to DZN15 group $(\mathrm{P}<0.05)$, however, there was a significant increase compared to control and placebo groups $(\mathrm{P}<0.05)$.

\section{Connective tissue volume}

The volume of connective tissue (Figure $1 \mathrm{H}$ ) was significantly increased in the DZN15 group compared to the control and placebo groups $(\mathrm{P}<0.05)$. There was no significant difference between the SMAE100, LC300, SAME100+LC300, DZN15+LC300, DZN15+SMAE100, and DZN15+SMAE100+LC300 groups compared to control and placebo groups $(\mathrm{P}>0.05)$.

\section{Histopathologic findings}

Histopathological findings show no evidence of hepatocyte injury and central vein in control (Figure 2A) and placebo (Figure 2B) groups. Hepatocytes are placed regularly without any damage and the liver tissue is perfectly normal.

In the DZN15 group (Figure 2C), hyperemia, destruction of sinusoids, lobular center vein coagulation necrosis, hepatocyte atrophy, and moderate to severe vacuolar cell resorption of interstitial cells were observed. Lymphocytic infiltration, apoptosis, and congestion were also observed in this group. Coagulation necrosis or fragmentation and lubrication of the cell nuclei and eosinophilization of their cytoplasm were detected and the inflammatory response around necrosis was severe. Liver hepatocytes were damaged and disrupted in such a way that the disorder and the pancreatic nucleus were largely observed in them. In this group, an increase in inflammatory cells and fibrosis was visible. No sign of tissue changes or tissue damage was observed in the SMAE100 (Figure 2D), LC300 (Figure 2E), and SAME100+LC300 (Figure 2F) groups.

Histopathological changes were reduced in the DZN15+LC300 group (Figure 2G) but in some parts of the hepatic tissue, hyperemia, sinusoids destruction, lobular center vein coagulation necrosis and mild to moderate vacuolar cell degradation in interstitial cells were observed. Lymphocytic inflammation and the presence of vacuolar spaces in the cytoplasm were observed in groups with a relative improvement of liver tissue compared to the DZN15 group. In the DZN15+SMAE100 group (Figure 2H), some local inflammation and lymphocytic infiltration were observed at some points. Apoptosis, congestion, hyperemia, and ballooning of hepatocytes were also observed. Coagulation necrosis or pycnosis, cell division, and lysis of the cells and eosinophilization of their cytoplasm were detected and the inflammatory response around necrosis was mild.

In DZN15+SMAE100+LC300 group (Figure 2I), histopathologic lesions were significantly reduced. There was also a significant decrease in congestion, hyperemia and tissue inflammation so that the histological structure of liver tissue was almost normal and comparable to control and placebo groups. 

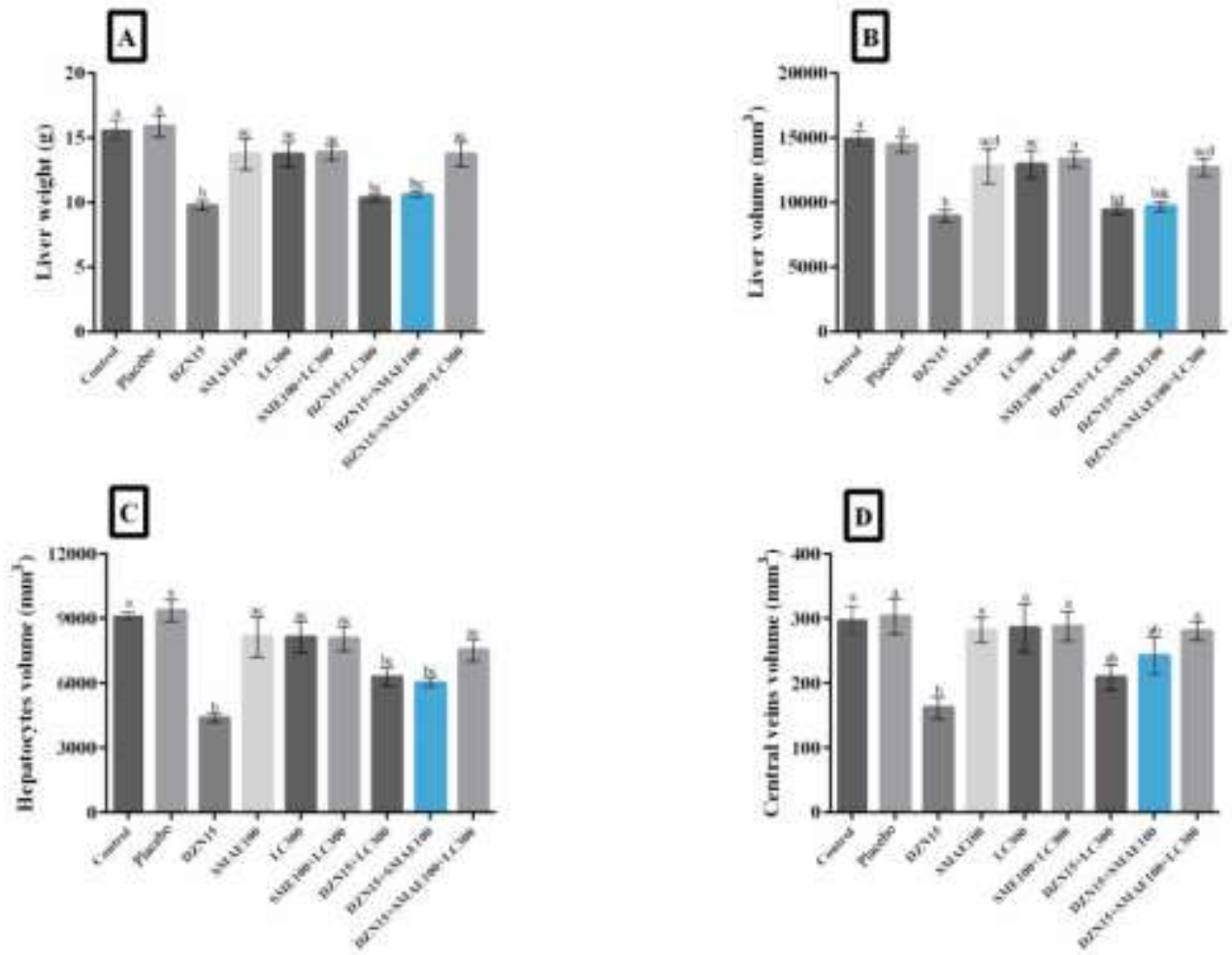

D

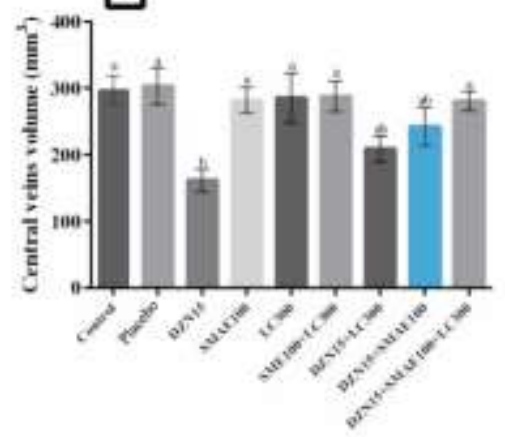

E
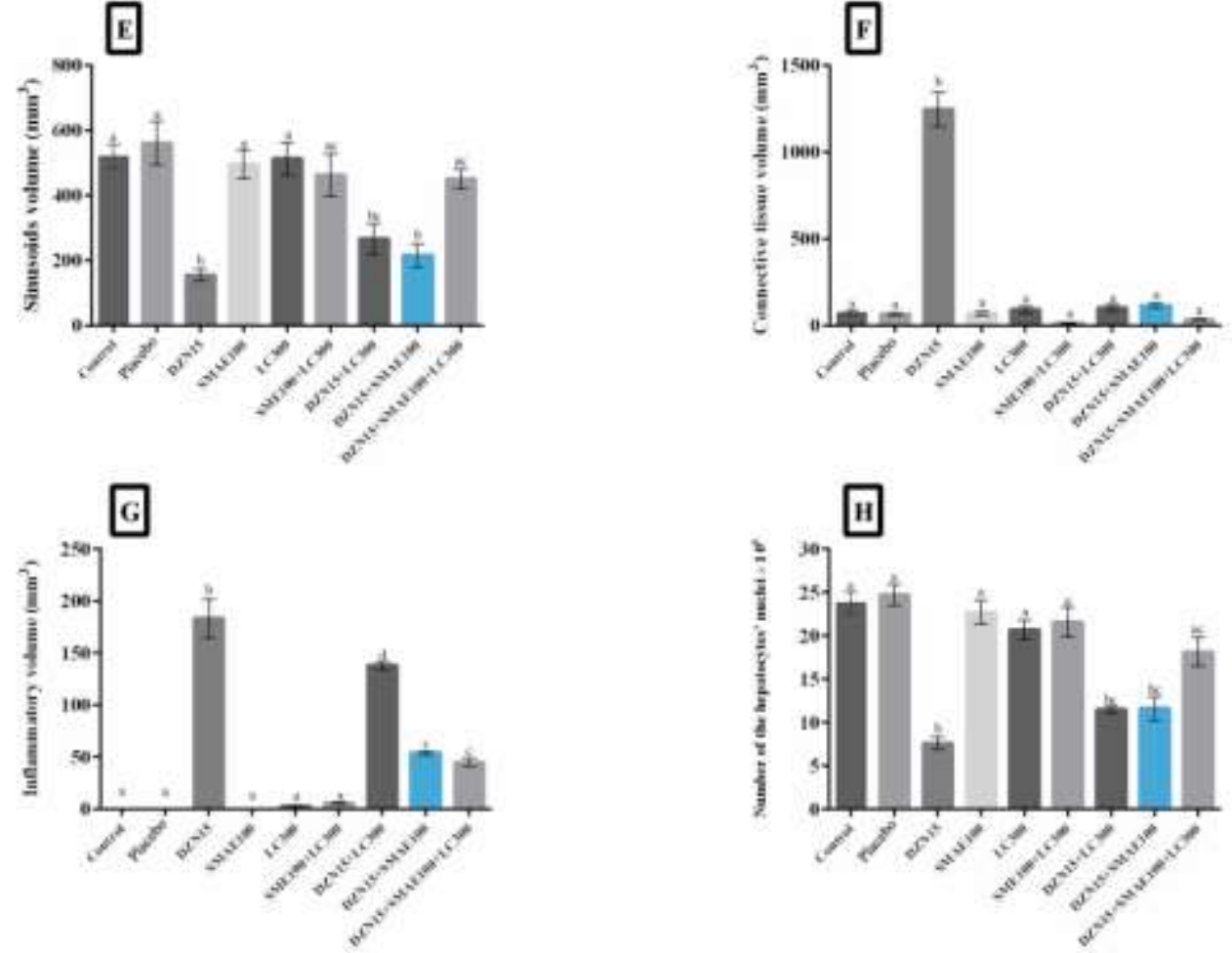

Figure 1. Evaluation of the liver weight (A), total volume of the liver (B), hepatocytes (C), central veins (D), sinusoids (E), connective tissue or fibrosis $(F)$ inflammatory area $(G)$ and number of the hepatocytes' nuclei $(H)$ in the control, placebo, Diazinon (DZN15), Silybum marianum (SMAE100), L-carnitine (Lc300), SMAE100+LC300, DZN15+ LC300, DZN15+SMAE100, and DZN15+SMAE100+LC300 groups. a, b, c and d: According to post-hoc Tukey test which was used to make intergroup comparisons groups with same superscripts were not significantly different at $(\mathrm{P}>0.05)$. However, dissimilar letters indicate a significant difference $(\mathrm{P}<0.05)$. 


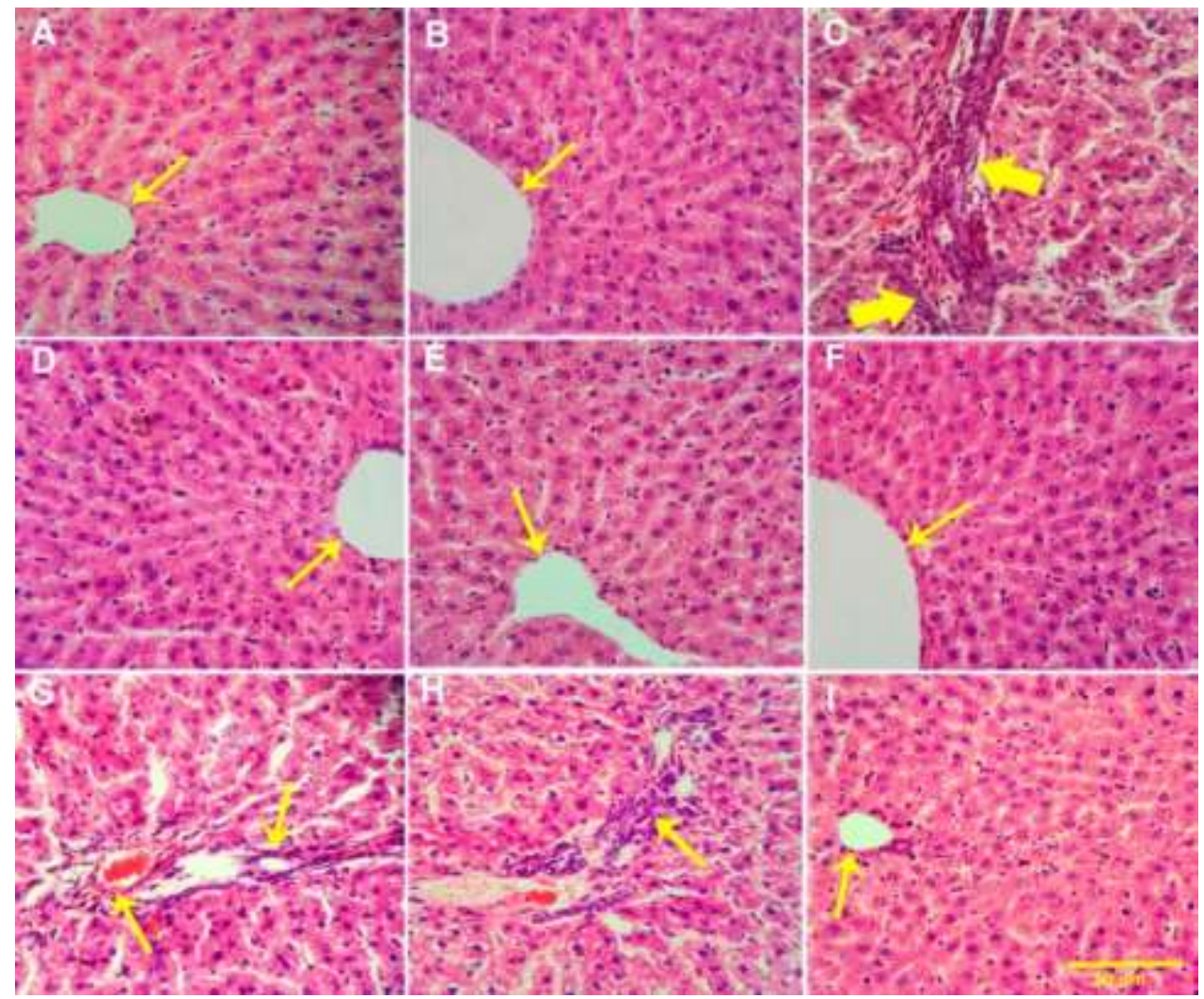

Figure 2. Photomicrograph of the rat's livers in the control (A), placebo (B), DZN15 (C), SMAE100 (D), LC300 (E), SMAE100+LC300 (F), DZN15+LC300 (G), DZN15+SMAE100 (H), DZN15+SMAE100+LC300 (I) groups. Stained with hematoxylin and eosin (H\&E) stain and magnification at $\times 100$. Control (A), and placebo (B), rats with normal hepatocytes and normal central vein (yellow thin arrow). In the DZN15-treated rat (C), a little number of hepatocytes' nuclei, lesser sinusoidal space volume and central vein volume, and increase bridge of the connective tissue or fibrous tissue (yellow pick arrows) can be seen. No structural changes were detected in the rat treated with SMAE100 (D), LC300 (E) and SMAE100+LC300 (F). DZN15 rats treated with LC300 (G), and SMAE100 (H), showed lymphocytic inflammation (yellow thin arrow) and vacuolization of cytoplasm. In the rat treated with DZN15+SMAE100+LC300 (I), a smaller number of hepatocytes' nuclei, normal central vein (yellow thin arrow), lesser accumulation of the fibrous tissue, and larger sinusoidal space can be observed

\section{Discussion}

In the present study, treatment with DZN toxin increased liver weight and volume, hepatocyte volume, central venous volume, sinusoidal volume, and hepatocyte nucleus volume and in contrast, it increased inflammation and liver fibrosis. The studies have shown that organophosphate toxins react with macromolecules and cell macromolecules and caused cellular and genetic damage (Li et al. 2015).

Organophosphorus insecticides can produce free radicals and disrupt the body's antioxidant systems. There is a balance between the production and removal of free radicals in natural conditions and oxidative stress is caused by the imbalance in these processes. Due to their tendency to absorb electrons, free radicals can damage important macromolecules such as proteins, lipids, and DNA (Li et al. 2015; Pearson \& Patel 2016).

Organophosphates degrade various cells and tissues of the body by increasing lipid peroxidation, cell apoptosis, and the production of free radicals, and they also inhibit the antioxidant activity of some enzymes like superoxide dismutase, glutathione peroxidase and catalase (Prokić et al. 2017; Eroglu et al. 2013).

Histopathologic damage in DZN toxin-treatment groups appears to be associated with increased oxidative stress and the induction of cell death. Also, the results of this study show that in groups treated with SMAE and LC, improvement of stereological and histopathologic indices is seen in comparison with the DZN toxin treatment group.

Considering the stereological and histopathological results of this study, it is concluded that the mechanism of SMAE and LC is to prevent oxidative stress induced by DZN in different parts of the liver. In living beings, there are two antioxidant systems to counteract the damaging effects of free radicals and oxidative stress which includes enzymatic antioxidant defense (Superoxide dismutase, glutathione peroxidase, catalase) and non-enzymatic include ascorbic acid, alpha-tocopherol, bilirubin, uric acid, polyphenols and 
carotene (Eroglu et al. 2013; Soto-Méndez et al. 2016). These compounds minimize the damage caused by free radical activity by preventing the production of free radicals and repairing the damaged tissues (Valko et al. 2016). Therefore, it seems that the SMAE and LC in rats treated with $\mathrm{DZN}$, due to the function of phenolic compounds (SMAE) and their antioxidant properties, inhibits the toxic and oxidative effect of DZN and plays a protective role for body cells.

Abdel-Daim et al. (2016) studied, using DZN toxin at a dose of $20 \mathrm{mg} / \mathrm{kg}$ for 4 weeks the level of biochemical parameters associated with liver injury was increased significantly like hepatic enzymes of alanine aminotransferase, aspartate aminotransferase, alkaline phosphatase, and gamma-glutamyltransferase. However, sesame oil and lipoic acid supplementation were able to reduce the toxic effect of DZN in rats by inhibiting free radicals and enhancing antioxidant activity.

In the study of Messarah et al. (2013), the protective effect of Curcuma longa and vitamin E on DZNinduced oxidative damage in rat liver was investigated. Diazinon increased lipid peroxidation and thiobarbituric acid reactive substrate levels. Diazinon increased alanine aminotransferase, aspartate aminotransferase, and alkaline phosphatase. In this study, it was shown that Curcuma longa and vitamin E can inhibit the toxic effects of DZN.

The antioxidant and protective properties of SM against a variety of free radical species have been proven in some studies (Negahdary et al. 2015; Zahkouk et al. 2015). In vitro studies have shown that the antioxidant properties of SM against oxidative stress injury are similar to the biological antioxidant glutathione (GSH) and even significantly greater than vitamin E (Surai 2015). However, the antioxidant effects of SM have not been fully understood but some of its mediating features have been shown through the cleansing of free radicals, reducing the activity of the enzymes responsible for producing free radicals, maintaining the integrity of the electron transport chain in the mitochondria, maintaining optimal redox state of the cell by activating a wide range of antioxidant and non-antioxidant enzymes and it has been shown mainly through transcription factors including nuclear factor erythroid-2-related factor 2 (Nrf2) and nuclear factor kappa-light-chain-enhancer of activated B cells $(\mathrm{Nf}-\mathrm{k} \beta)$ (Negahdary et al. 2015; Surai 2015).

\section{CONCLUSION}

Generally, the results of this study indicate that diazinon (DZN) toxin causes severe damage to rat liver tissue. Diazinon appears to exert its toxic effects on liver tissue by increasing inflammatory cells and fibrosis. On the other hand, concomitant use of SMAE and LC has protective and beneficial effects in DZNtreated rat's liver. The protective effects of the SMAE and LC appear to be probably due to the reduction of tissue inflammation.

\section{ACKNOWLEDGMENT}

The authors wish to thank the Kazerun Islamic Azad University for its financial (Grant No: IR. Kiau.1523050997) and for the technical supports.

\section{REFERENCES}

Abdel-Daim MM, Taha R, Ghazy EW, El-Sayed YS. 2016. Synergistic ameliorative effects of sesame oil and alphalipoic acid against subacute diazinon toxicity in rats: hematological, biochemical, and antioxidant studies. Can J Physiol Pharmacol 94:81-88.

Abenavoli L, Izzo AA, Milić N, Cicala C, Santini A, Capasso R. 2018. Milk thistle (Silybum marianum): A concise overview on its chemistry, pharmacological, and nutraceutical uses in liver diseases. Phyther Res. 32:2202-2213.

Anbarkeh FR, Nikravesh MR, Jalali M, Sadeghnia HR, Sargazi Z, Mohammdzadeh L. 2014. Single dose effect of diazinon on biochemical parameters in testis tissue of adult rats and the protective effect of vitamin E. Iran J Reprod Med. 12:731-736.

Beydilli H, Yilmaz N, Cetin ES, Topal Y, Celik OI, Sahin C, Topal H, Cigerci IH, Sozen H. 2015. Evaluation of the protective effect of silibinin against diazinon induced hepatotoxicity and free-radical damage in rat liver. Iran Red Crescent Med J. 17:1-7.

Bijak M. 2017. Silybin, a major bioactive component of milk thistle (Silybum marianum L. Gaernt.) - chemistry, bioavailability, and metabolism. Molecules. 22:1942.

Duysen EG, Cashman JR, Schopfer LM, Nachon F, Masson P, Lockridge O. 2012. Differential sensitivity of plasma carboxylesterase-null mice to parathion, chlorpyrifos and chlorpyrifos oxon, but not to diazinon, dichlorvos, diisopropylfluorophosphate, cresyl saligenin phosphate, cyclosarin thiocholine, tabun thiocholine, and carbofu. Chem Biol Interact. 195:189-198.

Eroglu S, Pandir D, Uzun FG, Bas H. 2013. Protective role of vitamins $\mathrm{C}$ and $\mathrm{E}$ in diclorvos-induced oxidative stress in human erythrocytes in vitro. Biol Res. 46:33-38.

Ghoreyshi S, Omri B, Chalghoumi R, Bouyeh M, Seidavi A, Dadashbeiki M, Lucarini M, Durazzo A, van den Hoven R, Santini A. 2019. Effects of dietary supplementation of L-carnitine and excess lysine-methionine on growth performance, carcass characteristics, and immunity markers of broiler chicken. Animals. 9:362.

Hodges RE, Minich DM. 2015. Modulation of metabolic detoxification pathways using foods and food-derived 
components: a scientific review with clinical application. J Nutr Metab. 2015:1-23.

Hussei AS, Abd El- OM, Hemdan HS. 2014. Protective effect of L-carnitine on metabolic disorders, oxidative stress, antioxidant status and inflammation in a rat model of insulin resistance. Int J Biol Chem. 8:21-36.

Jones RR, Barone-Adesi F, Koutros S, Lerro CC, Blair A, Lubin J, Heltshe SL, Hoppin JA, Alavanja MCR, Beane Freeman LE. 2015. Incidence of solid tumours among pesticide applicators exposed to the organophosphate insecticide diazinon in the Agricultural Health Study: an updated analysis. Occup Environ Med. 72:496-503.

Karimi A, Majlesi M, Rafieian-Kopaei M. 2015. Herbal versus synthetic drugs; beliefs and facts. J nephropharmacology. 4:27-30.

Li D, Huang Q, Lu M, Zhang L, Yang Z, Zong M, Tao L. 2015. The organophosphate insecticide chlorpyrifos confers its genotoxic effects by inducing DNA damage and cell apoptosis. Chemosphere. 135:387-393.

Messarah M, Amamra W, Boumendjel A, Barkat L, Bouasla I, Abdennour C, Boulakoud MS, Feki A El. 2013. Ameliorating effects of curcumin and vitamin $\mathrm{E}$ on diazinon-induced oxidative damage in rat liver and erythrocytes. Toxicol Ind Health. 29:77-88.

Murali P, George SK, Ally K, Dipu MT. 2015. Effect of Lcarnitine supplementation on growth performance, nutrient utilization, and nitrogen balance of broilers fed with animal fat. Vet World. 8:482-486.

Nasri H. 2013. Renoprotective effects of garlic. J Ren Inj Prev. 2:27-28.

Negahdary M, Bezhgi M, Ajdary M. 2015. Effects of Silymarin on Oxidative Stress Markers in Rats Treated with Magnesium Oxide Nanoparticles. Annu Res Rev Biol. 5:254-261.

Newcomb RD, Gleeson DM, Yong CG, Russell RJ, Oakeshott JG. 2005. Multiple mutations and gene duplications conferring organophosphorus insecticide resistance have been selected at the Rop-1 locus of the sheep blowfly, Lucilia cuprina. J Mol Evol. 60:207-220.

Pearson JN, Patel M. 2016. The role of oxidative stress in organophosphate and nerve agent toxicity. Ann N Y Acad Sci. 1378:17-24.

Prokić M, Borković-Mitić S, Krizmanić I, Gavrić J, Despotović S, Gavrilović B, Radovanović T, Pavlović S, Saičić Z. 2017. Comparative study of oxidative stress parameters and acetylcholinesterase activity in the liver of Pelophylax esculentus complex frogs. Saudi J Biol Sci. 24:51-58.

Sajadi SM, Nasrollahzadeh M, Maham M. 2016. Aqueous extract from seeds of Silybum marianum L. as a green material for preparation of the $\mathrm{Cu} / \mathrm{Fe} 3 \mathrm{O} 4$ nanoparticles: A magnetically recoverable and reusable catalyst for the reduction of nitroarenes. J Colloid Interface Sci. 469:93-98.

Scherle W. 1970. A simple method for volumetry of organs in quantitative stereology. Mikroskopie. 26:57-60.

Slotkin TA, Seidler FJ. 2012. Developmental neurotoxicity of organophosphates targets cell cycle and apoptosis, revealed by transcriptional profiles in vivo and in vitro. Neurotoxicol Teratol. 34:232-241.

Soto-Méndez MJ, Aguilera CM, Mesa MD, Campaña-Martín L, Martín-Laguna V, Solomons NW, Schümann K, Gil Á. 2016. Strong associations exist among oxidative stress and antioxidant biomarkers in the circulating, cellular and urinary anatomical compartments in Guatemalan children from the Western Highlands. Vrana KE, editor. PLoS One. 11:e0146921.

Surai P. 2015. Silymarin as a Natural Antioxidant: An Overview of the Current Evidence and Perspectives. Antioxidants. 4:204-247.

Trefts E, Gannon M, Wasserman DH. 2017. The liver. Curr Biol. 27:R1147-R1151.

Valko M, Jomova K, Rhodes CJ, Kuča K, Musílek K. 2016. Redox- and non-redox-metal-induced formation of free radicals and their role in human disease. Arch Toxicol. 90:1-37.

Xiong F, Guan Y-S. 2017. Cautiously using natural medicine to treat liver problems. World J Gastroenterol. 23:33883395 .

Zahkouk SA, El-Gendy AM, Eid FA, El-Tahway NA, ElShamy SA. 2015. Physiological and Histological Studies on the Heart of Male Albino Rats Exposed to Electromagnetic Field and the Protective Role of Silymarin and/Orvitamin E. Egypt J Hosp Med. 58:94108.

Zare S, Hossein Dabbaghmanesh M, Noorafshan A, Koohpeyma F, Bakhshayeshkaram M, MontazeriNajafabady N. 2019. Protective effect of vitamin E and vitamin $\mathrm{C}$ alone and in combination on testicular damage induced by sodium metabisulphite in rats: A stereological study. Andrologia. 51:e13193. 